UDK 784.3Savin

Aleš Nagode

Filozofska fakulteta, Univerza v Ljubljani

Faculty of Arts, University of Ljubljana

\title{
Med domom in svetom: Pesmi za glas in klavir Rista Savina
}

\section{Between the Homeland and the Wider World: Songs for Voice and Piano by Risto Savin}

Prejeto: 12. april 2012

Sprejeto: 14. september 2012

Ključne besede: 19. stoletje, 20. stoletje, Risto Savin, samospev, narodni preporod

IZVLEČEK

Članek ponuja nov pogled na gradivo povezano z ustvarjalnostjo Rista Savina za glas in klavir. Opozarja na nekaj doslej spregledanih skladb ter poskuša z razširjenim naborom dejstev korigirati uveljavljeno kronologijo nastajanja del. Izsledki znatno spreminjajo dosedanje razumevanje Savinove ustvarjalnosti. Njegova opredelitev za slovensko nacionalno gibanje ni bila nenaden zasuk, kot je to veljalo do sedaj, temveč rezultat dolgotrajnega odzivanja na pobude iz kulturnega okolja, v katerem je deloval.
Received: 12th April 2012

Accepted: 14th September 2012

Keywords: nineteenth century, twentieth century, Risto Savin, Slovene song, German Lied, national revival

ABSTRact

The article presents a new view on the material linked to Risto Savin's songs for voice and piano. It draws attention to several songs that have thus far been unaccounted for and uses a range of facts to correct the established chronology of Savin's songs. The results of this research considerably alter our understanding of Savin's creativity. His decision to associate himself with the Slovene national movement was not an instant turning point, as has been believed, but rather a result of a long-term response to the intiatives from the cultural environment in which he worked.

Pesem je v 19. stoletju brez dvoma sodila med najpomembnejše glasbene žanre. Današnji opazovalec, ki lahko dejstva o glasbi tega časa spoznava predvsem s posredovanjem strokovne in znanstvene literature, bi sicer lahko dobil vtis, da je bila v senci drugih glasbenih zvrsti, predvsem glasbeno-scenske in simfonične glasbe. A že površen pregled ohranjenih dokumentov o koncertnih dogodkih pokaže, da so bile pesmi za različne zasedbe - od solista s klavirjem, preko vokalnega ansambla do različnih zbo- 
rovskih zasedb - najbolj številne in v glasbenem življenju najbolj vsestransko prisotne skladbe.

Posebno mesto, ki so ga zasedale v glasbi 19. stoletja, je bilo posledica spleta političnih in kulturnih okoliščin. Delček odgovora na vprašanje, zakaj je bila prav pesem deležna take pozornosti, razkriva dejstvo, da je pesemski repertoar v največjem obsegu nastajal prav v Srednji Evropi. Prebivalstvo tega dela celine je živelo v političnih okvirih, ki niso ustrezali prevladujočim nacionalističnim težnjam sodobnega evropskega meščanstva. Drugače kot v zahodni Evropi, kjer so si nastajajoče meščanske elite lahko prisvojile že oblikovano identiteto velikih centraliziranih monarhij, se je srednja Evropa, razdrobljena v politične okvire, ki so bili dediščina fevdalnega partikularizma, krčevito borila za oblikovanje sodobnih nacionalnih držav. Ključno orodje za vzpostavitev vsaj duhovne nacionalne enotnosti je postala kultura, zlasti pa tisti del, ki je bil tako ali drugače povezan z rabo knjižnega jezika. Na njem je najprej temeljila zavest o enotnosti vseh Nemcev, kasneje pa so ta ključni določevalni dejavnik povzeli tudi drugi srednjeevropski narodi.

$\mathrm{V}$ tem procesu je pesem doživela popolno vsebinsko in funkcionalno preobrazbo. Če je bila vse do sredine 19. stoletja intimna zvrst, zasidrana v območju vedre, morda kvečjemu sentimentalne družabnosti in sorazmerno neodvisna od zunanjih estetskih, političnih in finančnih določitev, je v drugi polovici stoletja postala osrednje torišče nacionalnega prebujanja. Neizbežna tesna povezanost z jezikom in literaturo jo je nezadržno vsrkala v vrtinec političnega dogajanja. Ni naključje, da je pesemski repertoar najbogatejši pri narodih, ki v 19. stoletju niso imeli trdnega političnega okvira. Razumevanje njene vloge v javnem življenju se je tudi na Slovenskem - morda še izraziteje, kot v drugih evropskih okoljih - odvijal vzporedno z razvojem nacionalne ideje: od široke, multikulturne odprtosti za umetniške dosežke drugih jezikovnih skupin, do ekskluzivističnega purizma, ki je poskušal iz nacionalno čistega okolja izgnati vse, kar ni domače. Iz zvrsti za glasbenega ljubitelja je postala koncertna skladba, katere izvedba je bila vedno do določene mere tudi politična izjava.

Prav zato se tudi opazovanje ustvarjalnosti Rista Savina za glas in klavir v svojem izhodišču nujno nekoliko razlikuje od opazovanja del skladateljev, ki so delovali v drugačnih razmerah. Vsako glasbeno delo je namreč predvsem rezultat soodvisnosti med okoljem, ki je hkrati oblikovalo skladateljeva estetska in kompozicijska izhodišča ter določalo merila odmevnosti njegovih del, in skladateljevo inovativnostjo. Je svojevrsten seizmogram avtorjevega odločanja med različnimi možnostmi, ki se mu ponujajo v danih zunanjih okoliščinah.

Savinove skladbe za glas in klavir so zato izjemno uporabne za opazovanje skladateljevega osebnega razvoja in njegovega razmerja do okolja, v katerem je deloval. Njihova vrednost je toliko večja, saj jih v nasprotju z večjimi deli, npr. simfoničnimi ali glasbenoscenskimi, pri nastajanju in razširjanju ne omejujejo v tolikšni meri morebitne ekonomske in organizacijske omejitve. Zato bomo v nadaljevanju prispevka s pomočjo samospevov poskušali orisati in razumeti dinamiko spreminjanja skladateljevih ustvarjalnih in drugih nazorov ter poskušali na tej podlagi ponovno oceniti njegove ustvarjalne dosežke v tej Žanru, pa tudi do sedaj uveljavljene ocene strokovne kritike.

Iz virov, ki pričajo o Savinovi glasbeni zapuščini, je mogoče razbrati obseg pozornosti, ki jo je skladatelj namenih ustvarjanju za glas in klavir. Načrtoval, komponiral ali 
dokončal je skupno 41 skladb v tem žanru, od tega 16 na nemška in 25 na slovenska besedila. Nekatere od teh skladb niso povsem dokončane, spet druge pa so znane le po naslovu in so njihovi zapisi izgubljeni. Iz ohranjenega gradiva je le delno mogoče rekonstruirati kronologijo nastajanja tega repertoarja. Nekajkrat je to poskušal narediti skladatelj sam in izdelal več popisov del, ki jih hrani glasbena zbirka Narodne in univerzitetne knjižnica v Ljubljani. ${ }^{1}$ Njegovi seznami so sicer dokaj popolni, vendar v njih vseeno pogrešimo nekaj - po njegovem mnenju verjetno manj pomembnih - del. Precej zmede je prineslo tudi njegovo neprestano spreminjanje številk posameznih opusov, ki so zato le nezanesljiv pokazatelj za identifikacijo in kronološko zaporedje skladb. Na podlagi dostopnega gradiva je seznam del z najbolj osnovnimi podatki izdelal tudi Dragotin Cvetko za svojo monografijo o skladatelju. ${ }^{2}$ Zasnoval ga je kronološko, kar je nujno prineslo težave z umestitvijo skladb, za katere ni imel na voljo trdnih in na virih utemeljenih datacij. Pomanjkljive podatke je poskušal - kot bomo videli dokaj neuspešno - dopolniti z ugotovitvami stilne analize.

Že Cvetko je pravilno ugotovil, da je Savin svoja prva dela v tem žanru ustvaril na nemška besedila. Kronološko jih je umestil v čas študija pri Robertu Fuchsu in jim večinoma pripisal le skromno umetniško vrednost. Dejansko je mogoče v ta čas zanesljivo datirati le eno skladbo. Iz leta 1892 je gotovo Mädel, wie blüht's, podnaslovljena s Volkslied, katere rokopis nosi datum 1.4.1892. ${ }^{3}$ Medtem ko gradivo povezano s samospevi Lass das Fragen, Eh' ich sah in Bild der Nacht ne ponuja zanesljive podlage za datacijo, pa je mogoče nekoliko bolj natančno opredeliti ostale nemške samospeve, ki jih je Cvetko v svojem seznamu umestil v ta čas. Samospev Wald bei der Nacht je zelo verjetno nastal kar nekaj let kasneje, verjetno po letu 1898, kot je na podlagi zvez med pesnikom besedila in Savinom ugotovil Peter Zimmermann. ${ }^{4}$ Podobno je s skladbo Bist du braun, bist $d u$ blond. Cvetko je spregledal datacijo I/1900 na rokopisu, ${ }^{5}$ ki jo zopet potrjujejo tudi ugotovitve Petra Zimmermanna. ${ }^{6}$

Dodatno osnovo za datacijo lahko morda ponudi tudi primerjava notnega papirja, ki ga je Savin uporabljal za zapis svojih del. Čeprav so rokopisi njegovih del za glas in klavir na kar 27 različnih vrstah papirja - kar na nek način priča tudi o njegovi dinamični življenjski poti - se vseeno nakazujejo določene povezave, ki bi lahko kazale na kronološko bližino nekaterih del. Na enakem papirju kot Bist du braun, bist du blond sta še An die Entfernte in Ich schreite heim, ki bi jih zato lahko prej umestili v čas ok. leta 1900, kot na začetek prejšnjega desetletja.

V nadaljevanju seznama navaja Cvetko le še nekaj samospevov na nemška besedila. Zwei Lieder von Richard Sanneck, op. 18 (skladatelj je v seznamih del uporabljal tudi slovensko verzijo naslova) brez podrobnejše navedbe vira postavlja v leto 1901.7 Danes dostopno dokumentarno gradivo obsega rokopis, v katerem sta skladbi enoznačno datirani 3/[19]17 (Am Wege) in 4/[19]17 (Im Mai). Da je rokopis zelo verjetno nastal

\footnotetext{
Narodna in univerzitetna knjižnica (v nadaljevanju NUK), Ljubljana. Glasbena zbirka. Savin, Risto. Kronika, Seznami del. Dragotin Cvetko, Risto Savin: Osebnost in delo (Ljubljana: Državna založba Slovenije, 1949), 189-193.

NUK, Glasbena zbirka. Savin, Risto. Kronika, Seznami del. Skladbe K-N.

Peter Zimmermann, »Poesie und Trivialität in Risto Savins deutschen Liedtexten«, Muzikološki zbornik 48, št. 2 (2012): 104-105. NUK, Glasbena zbirka. Savin, Risto. Kronika, Seznami del. Skladbe A-J.

Zimmermann, "Poesie und Trivialität ...«, 98-99.

Cvetko, Risto Savin ..., 59.
} 
v označenem času priča tudi dejstvo, da so na podobnem papirju tudi nekateri drugi rokopisi, ki jih lahko enoznačno datiramo. ${ }^{8}$ Malo verjetno je tudi, da bi avtor ali drug prepisovalec izdelal prepisa starejših skladb istega niza s časovnim premorom enega meseca. Zato se ne zdi brez podlage domneva, da sta samospeva verjetneje kot leta 1901 nastala 1917.

Zelo malo zanesljivih sledi je tudi za kronološko umestitev samospeva Frühling. Cvetko ga je na podlagi stilistične analize postavil v leto 1906, kar pa je glede na druge pokazatelje malo verjetno. Prvi je brez dvoma uporaba podpisa Friederich Schirza na rokopisu skladbe, ki ga redno najdemo na skladbah iz zgodnjih devetdesetih let, kasneje pa je skladatelj dosledno uporabljal psevdonim. Drugi argument prinašajo znova ugotovitve Petra Zimmermanna, ki je uspel izslediti sorazmerno redko izdajo, ki je Savinu služila kot vir besedila in ki je izšla že leta 1893. ${ }^{9}$ Njena uporaba bil lahko prispevala k verjetnosti, da je samospev nastal že pred letom 1900.

Zadnja skladba na nemško besedilo, ki jo navaja Cvetkov seznam del, je Kosakisches Wiegenlied. Postavlja jo v leto 1920, tudi tokrat le na podlagi stilističnih potez in dejstva, da je napisan v nadaljevanju Sonate za čelo in klavir, op. 22 iz leta 1920. ${ }^{10}$

V svojem pregledu je Cvetko spregledal še tri skladbe na nemška besedila. Prva je Wintersonne, katere rokopis je na enakem papirju kot skladba Svetla noč iz niz Pet pesmi Otona Župančiča, op. 13, datirana v leto 1904. V zadnjih letih pa sta bili odkriti še dve, doslej povsem neznani deli: Abendfriede, ki je ni mogoče podrobneje datirati, in Barbarazweige, za katero bi lahko na podlagi ugotovitev Petra Zimmermanna o okoliščinah izida njenega besedila ${ }^{11}$ postavili domnevo, da je nastala po letu 1909.

Kronologija nastajanja samospevov na slovenska besedila je - vsaj v grobih potezah - bolj zanesljivo določljiva. Večina skladb je nastala v sorazmerno kratkem ustvarjalnem obdobju desetih let med sredino zadnjega desetletja 19. in sredino prvega desetletja 20. stoletja. Niz začenjajo Tri Aškerčeve balade, op. 3, ki jih je Savin skladal v zadnjih mesecih leta 1895. V pismu bratu Josipu z dne 20. 10. 1895 omenja, da sta dve že dokončani. V naslednjem pismu, z dne 25. 11. 1895 pa se opravičuje, da se je prepisovanje nekoliko zavleklo in da jih zato prilaga šele omenjenemu pismu. ${ }^{12}$

Nekoliko bolj nejasno je nastajanje naslednjih dveh opusov, niza Dve predsmrtnici, op. 10 in Skala $v$ Savinji, op. 9. V prvega je precej po nastanku povezal dve skladbi na besedilo Simona Gregorčiča (Kropiti te ne smem in Tone sonce). Prva je izšla že nekje na začetku leta 1903, v drugem letniku revije Novi akordi z naslovom Predsmrtnica. V avtorjevi zapuščini se je ohranila vrsta rokopisnih zapisov. ${ }^{13}$ Eden od njih nosi datum 1. 7. 1902, ki pa bi lahko označeval tudi datum prepisa, morda namenjenega uredništvu Novih akordov (rokopisa te skladbe sicer ni v arhivu uredništva Novih akordov). Drugi od rokopisov se po tipu uporabljenega papirja ujema s samospevom Ljubica zdaj je dan, ki je bil vključen v niz Pet pesmi Otona Župančiča, op. 13, ki pa je ni mogoče z

\footnotetext{
Npr. Tri pesmi Otona Župančiča iz 1918. NUK, Glasbena zbirka. Savin, Risto. Kronika, Seznami del. Skladbe U-Ž. Zimmermann, »Poesie und Trivialität ...«, 97-98.

NUK, Glasbena zbirka. Savin, Risto. Kronika, Seznami del. Skladbe S

Zimmermann, "Poesie und Trivialität ...", 102-103. Za opozorilo na obe novoodkriti skladbi se iskreno zahvaljujem Suzani Ograjenšek.

12 Suzana Ograjenšek, Priloga k diplomski nalogi Dopisovanje Rista Savina o glasbi in glasbenem dogajanju (Filozofska fakulteta, Oddelek za muzikologijo, Ljubljana, 1998-99), 123-124.

13 NUK, Glasbena zbirka. Savin, Risto. Kronika, Seznami del. Skladbe A-J.
} 
gotovostjo datirati. Tretji rokopis ni datiran, niti ga ni mogoče povezati z nobeno od skladb v skladateljevi zapuščini. Še več težav prinaša datacija samospeva Tone sonce. ${ }^{14}$ V zapuščini sta ohranjena dva rokopisa. Prvi nosi letnico 1903, drugi pa ni datiran, a je pisan na papirju tiskarne J[osef]. E[berle] \& Co. z Dunaja, ki ga je Savin uporabljal v dveh različnih obdobjih svojega življenja (med 1895 in 1902 in med 1917 in 1918). Tako sicer nič ne nasprotuje Cvetkovi, na stilni analizi utemeljeni dataciji obeh del v leto 1898, vendar se zarisuje tudi možnost, da je Savin izpopolnjevanje obeh skladb dejansko zaključil šele med poletjem 1902 in začetkom leta 1903.

V istem obdobju je morala nastati tudi Skala $v$ Savinji, op. 9, ki je prav tako izšla v drugem letniku Novih akordov leta 1903. Rokopisu, ki ga ni mogoče datirati ali kako drugače povezati s kakšno od datiranih skladb, je priložena obsežna korektura na papirju tiskarne J[osef]. E[berle] \& Co., kakršnega je Savin uporabljal tudi za drugo od Predsmrtnic, op. 10. Izgubljeni cvet, ki ga je Cvetko na podlagi stilne analize postavil v leti 1898 ali 1899 je zanesljivo datiran z datumom 25. 5. 1899 na rokopisu skladbe. ${ }^{15} \mathrm{~V}$ istem času je morala nastati tudi Zimska idila, op. 7, ki je leta 1900 brez letnice izšla v založbi Schwentner v Ljubljani. ${ }^{16} \mathrm{Njen}$ rokopis s prej omenjenimi skladbami izpred leta 1900 povezuje uporaba enakega papirja tiskarne J[osef]. E[berle] \& Co. ${ }^{17}$

Le par let kasneje sta nastali obe skladbi, ki ju je Savin - skupaj z nemškima samospevoma Eh' ich sah in Wald bei Nacht - vključil v zbirko Štiri pesmi za glas in klavir, op. 5. Rokopis pesmi Kaj bi te vprašal je datiral 25. 10. 1903, na rokopisu Pozabil sem mnogokaj dekle pa je le letnica 1903.18

Skladbe naslednjega niza Pet pesmi Otona Župančiča, op. 13, so verjetno nastajale v prvih letih 20. stoletja. Enoznačno sta datirana rokopisa skladb Svetla noč (1904) in Marica (I/1906). Pismo in To je sta morda nastali v letih 1905 ali 1906, saj sta na enakem papirju kot Marica. Zadnja skladba, Ljubica zdaj je dan, pa je sicer nedatirana, a zapisana na enakem papirju kot eden od rokopisov samospeva Kropiti te ne smem iz op. 10.19 Zato bi bila morda lahko celo najstarejša skladba tega niza.

Savin se je zopet lotil komponiranja samospevov šele po desetletnem premoru. Tri pesmi Otona Župančiča, op. 20, je verjetno zložil v drugi polovici leta 1918, na kar bi lahko sklepali na podlagi pripisa "na Silvestrovo 1918 « na zadnji strani zadnje pesmi. ${ }^{20}$ Skupino samospevov, ki jih lahko enoznačno umestimo v to obdobje, zaokrožujeta Čarne tvoje so oči, op. 29, št. 1, katerega rokopis je datiran 26. 10. $1921^{21}$ in Maškarada (Maskerada) op. 31 iz leta 1928. ${ }^{22}$

Ob navedenih skladbah pa je v delu Savinove zapuščine, ki jo hrani Glasbena zbirka Narodne in univerzitetne knjižnice v Ljubljani, še nekaj nedatiranih samospevov na slovenska besedila. Najzgodnejša je verjetno Ponočna potnica, ki je Cvetko v času pisanja svoje monografije očitno še ni imel na razpolago. Med skladbe zgodnejšega

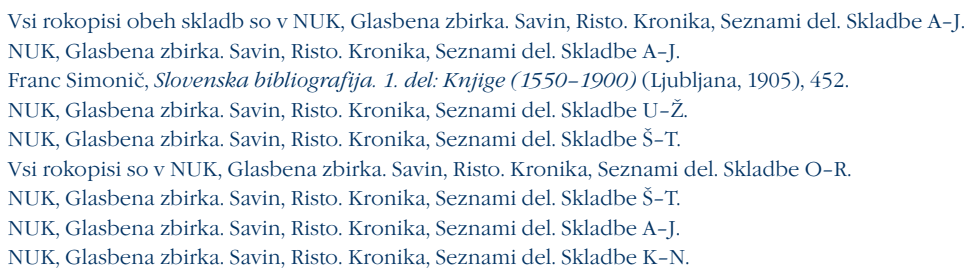


obdobja bi jo lahko uvrstili na podlagi več posrednih sledi. Skladatelj je posegel po besedilu Antona Aškerca, ki ga je navduševal predvsem v času ok. leta 1900. V dvajsetih letih je uporabljal predvsem besedila mlajše generacije slovenskih pesnikov. S starejšimi samospevi jo povezuje tudi izrazito baladni značaj. Bližino nastanka obeh del morda izpričuje tudi avtorjev prvotni načrt, da bi jo skupaj z Zimsko idilo, komponirano leta 1900, povezal v op. $4 .^{23}$

Ostala nedatirana dela brez dvoma sodijo v dvajseta leta. Romanca, na besedilo Srečka Kosovela, ni mogla nastati prej, saj je pesnik v tem času šele začenjal s svojim ustvarjanjem. Dragotin Cvetko jo je na podlagi stilističnih značilnosti umestil v leto 1922. V svoji monografiji navaja tudi, da naj bi bila skupaj s Kosakisches Wiegenlied napisana na nadaljevanju papirja Sonate za violončelo in klavir, op. 22 iz leta 1920, kar bi dajalo domnevi nekoliko večjo težo. ${ }^{24}$ Medtem ko Cvetkova navedba za Kosakisches Wiegenlied drži, ${ }^{25}$ pa je edini rokopisni izvod Romance v Savinovi zapuščini pisan na povsem drugačnem papirju. ${ }^{26}$ Domneva, da je samospev nastal že leta 1920, je še nekoliko manj verjetna ob dejstvu, da je Kosovelovo besedilo prvič izšlo šele leta 1927 v zbirki Pesmi ${ }^{27}$ Zato je veliko verjetnejša domneva, da je skladba nastala ob koncu dvajsetih let.

Podobno velja za nekončan samospev Molče v večer sem šel, ki ga prav tako ni v Cvetkovem seznamu del. Savin ga je verjetno komponiral najprej v drugi polovici leta 1927, ko je v prvi številki revije Svobodna mladina izšlo besedilo Vladimirja Premruja. ${ }^{28}$ V skupino del iz dvajsetih let sodi tudi nedokončani April, katerega nastanek je Cvetko sodeč po predvidenem opusu 25 (ki ga imata sicer tudi Dva četverospeva iz leta 1926) umestil v leto 1926 ali $1927 .{ }^{29}$

Zgolj po naslovu poznamo samospev Pomladi, ki ga je hotel Savin skupaj s Čarne tvoje so oči, kot številko dve povezati v opus 29. O njem priča le napis na skupni mapi, v kateri pa je danes le rokopis prvega samospeva. Morda gre za samospev Frühling iz zgodnejšega obdobja. Povezovanje zgodnejših in kasnejših ter nemških in slovenskih del v enoten niz ni izključen, saj je na podoben način oblikovan tudi niz Štiri pesmi za glas in klavir, op. 5.

Obsežen opus samospevov na nemška besedila je - vsaj kolikor je mogoče sklepati po dostopnih podatkih - ostal v veliki meri neznan širši javnosti. Nobena od skladb ni izšla v tisku, zdi pa se tudi, da si Savin ni posebej prizadeval, da bi izvajalcem omogočil dostop do njih. Leta 1937 se je pisec besedil samospevov Am Wege in Im Mai, Richard Watzlawek - Sanneck nanj obrnil s pobudo, da mu posreduje rokopise obeh pesmi. Sanneck je bil v tem času zastopnik znanega češkega tenorista Richarda Kuble, ki bi $\mathrm{v}$ sporede svojih koncertov in načrtovane turneje po Jugoslaviji uvrstil tudi Savinove skladbe. Skladateljev odgovor je bil dokaj hladen. Izgovoril se je, da nima pripravljenih prepisov skladb, da bi prepisovanje terjalo preveč časa in da Sanneck lahko skladbe

23 Prim. ustrezne oznake na obeh rokopisih. NUK, Glasbena zbirka. Savin, Risto. Kronika, Seznami del. Skladbe O-R in skladbe $\mathrm{U}-\mathrm{Z}$.

Cvetko, Risto Savin ..., 106.

25 NUK, Glasbena zbirka. Savin, Risto. Kronika, Seznami del. Skladbe S, Mapa Sonata za violončeno in klavir, op. 22.

26 NUK, Glasbena zbirka. Savin, Risto. Kronika, Seznami del. Skladbe O-R.

77 Anton Ocvirk, ur., Srečko Kosovel: Zbrano delo: Zbrana dela slovenskih pesnikov in pisateljev, 1. zvezek (Ljubljana: Državna založba Slovenije, 1964), 447. Morda bi jo lahko Savin povzel tudi po skoraj sočasni objavi v reviji Mladina 3 (1926/27): 74.

28 Vladimir Premru, »Molče v večer sem šel«, Svobodna mladina 1 (1927/28): 57.

29 Cvetko, Risto Savin ..., 156. 
dobi, če bo v času turneje na obisku v Jugoslaviji. Vzrok za Savinovo zadržanost do Sanneckove pobude bi lahko bila sicer tudi osebna zamera, katere vzrok je bilo Sanneckovo neuspešno, a drago posredovanje za izvedbo Savinove opere Lepa Vida na Dunaju. ${ }^{30}$

Nekoliko bolj znane so bile skladbe na slovenska besedila. Sorazmerno kmalu po nastanku, domnevno 1899 in 1900, so v založbi Schwentner v Ljubljani izšle Zimska idila, op. 7 in Tri Aškerčeve balade, op. 3. V drugem letniku revije Novi akordi so 1903 izšle Predsmrtnica (Kropiti te ne smem) in Skala v Savinji, op. 9. Naslednji samospevi so v tisku izšli šele iz leta 1921, ko je Savin v založbi Goričar in Leskovšek iz Celja izdal zbirki Pet pesmi Otona Župančiča, op. 13 in Tri pesmi Otona Župančiča, op. 20. V začetku tridesetih let si je dopisoval z Ludvikom Zepičem v zvezi z izvedbo nekaterih samospevov (Skala v Savinji, Maškarada, Čarne tvoje so oči) na koncertih v Ljubljani, Ptuju in Beogradu. ${ }^{31}$

Sorazmeren je bil tudi odziv strokovne javnosti. Medtem ko o nemških skladbah nimamo nobenega kritičnega zapisa, so bile večinoma ugodnih ocen deležne natisnjene slovenske skladbe. Gojmir Krek je v leta 1901 ugodno, a nekoliko zadržano ocenil Tri Aškerčeve balade in Zimsko idilo. Prepoznal je skladateljev smisel za ustvarjanje baladnih vzdušij, primerno deklamacijo, všečno melodiko, domiselno rabo harmonskih možnosti in bogato oblikovanje klavirskega stavka. ${ }^{32}$ Do podobnih ugotovitev je prišel tudi Vladimir Foerster, ki je v skladbi Skala v Savinji najbolj pohvalil smisel skladatelja za slikanje baladnega vzdušja in bogato, skoraj simfonično klavirsko spremljavo. ${ }^{33}$ Anton Lajovic je nekaj let kasneje Savinove samospeve s preloma stoletja označil kot "znanilke novih časov«, kot glasbo, ki je »krepka, mladostno brezobzirna glasba, ubirajoča predrzne moderne harmonije, v jezo in ogorčenje naših tedanjih kritičnih kvintolovcev. « ${ }^{34}$ A navdušenje nad Savinovim delom se je postopno ohlajalo. Patetične oznake, ki jih srečamo v Lajovčevem zapisu, so se pri naslednji generaciji ohladile. Kogoj je v pregledu slovenske ustvarjalnosti za glas in klavir hladno ugotovil, da je Savin "napravil nekaj samospevov, ki so prav izrazite skladbe. ${ }^{35}$ Že leto pred tem pa je precej zmerno pohvalil zbirko Pet pesmi Otona Župančiča in kot popolnoma nepotrebno označil Tri pesmi Otona Župančiča. ${ }^{36}$

Zgodovinski lik Rista Savina, znanilca moderne in dviga slovenske nacionalne kulture na evropsko raven, je do konca izrisal Dragotin Cvetko s svojo monografijo iz leta 1949, ki še danes ostaja edina podrobna, celovita in znanstveno utemeljena obravnava skladateljevega življenja in dela. Njegovo videnje so močno zaznamovala metodološka izhodišča, na katerih temeljijo tudi ostala Cvetkova dela o zgodovini glasbe na Slovenskem. Savinovo ustvarjalnost je opazoval na podlagi dveh, zanj nespornih in naravno pogojenih razvojnih procesov. Prvi je bil stilistični razvoj evropske umetne glasbe, ki ga je razumel kot stalen napredek v odkrivanju vedno bolj izpopolnjenih skladateljskih izraznih sredstev. Kvaliteta glasbenega dela je bila po njegovem mnenju v pretežni meri

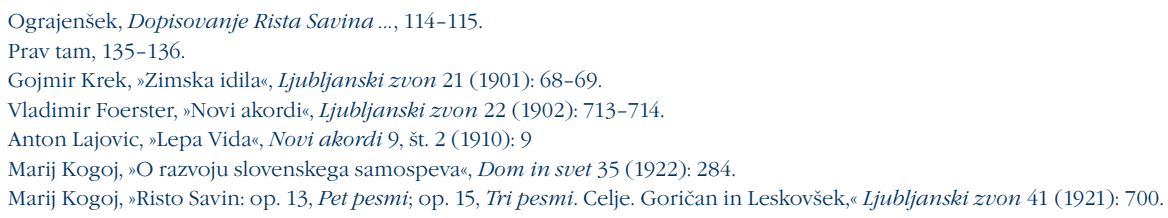


odvisna od čim večje uporabe zadnjih novosti sodobne kompozicijske prakse. Drugo merilo, s katerim je Cvetko meril estetski, s tem pa implicitno tudi zgodovinski pomen na Slovenskem nastalih glasbenih del, pa je njihov prispevek k razvoju in uveljavitvi samobitne slovenske nacionalne glasbene kulture. Po njegovem mnenju je pomembna le tista glasba, ki s svojimi potezami izpričuje narodno zavednost svojega avtorja.

Cvetkov metodološki pristop pove več o zgodovinopiscu in o času, v katerem je bil uporabljen, kot o predmetu opazovanja. Njegova interpretacija Savinove ustvarjalnosti je prej skrbno retuširana slika, kot prikaz in razčlemba dejanskega zgodovinskega dogajanja. Prikazuje jo tako, kot so si jo udeleženi - zavedno ali nezavedno - želeli videti. Težnja po jasni, z obema že omenjenima vodilnima procesoma strukturirani pripovedi o Savinovem delu, je Cvetka zapeljala v tavtološko opazovanje njegovih del. Svoje ugotovitve o skladateljevem ustvarjalnem razvoju je največkrat utemeljil na domnevnih datacijah skladateljevih del, ki pa jih je določil sam, največkrat izključno na podlagi teh istih, vnaprej postavljenih ugotovitev.

Dopolnjena in deloma korigirana datacija Savinovih del za glas in klavir zato pomembno spreminja Cvetkovo poenostavljeno videnje skladatelja, ki z vsako naslednjo skladbo stopa naprej na poti od posnemanja uveljavljenih tradicionalnih zgledov proti avtonomnemu odkrivanju širnih prostranstev modernistične izraznosti in od nacionalne neopredeljenosti proti vlogi enega od prerokov nacionalne glasbe. Pri podrobnejšem opazovanju se Cvetkovi jasno usmerjeni razvojni tok razlije v vrsto vzporednih, v različne smeri tipajočih procesov. Savinova dela za glas in klavir niso postaje na jasno usmerjeni poti, ampak množica avtonomnih zgodovinskih dogodkov. Vsak zase je pogojeni s spletom spremenljivih osebnih in zunanjih okoliščin, ki je ključno določal skladateljeve ustvarjalne odločitve.

Najprej se ozrimo na Savinovo izbiro jezika besedil za uglasbitev. Cvetko je v svoji monografiji nastanek večine samospevov na nemška besedila postavil v prvo polovico devetdesetih let in njihov nastanek pojasnil - bolje bi rekli opravičil - s študijskimi nalogami pri Robertu Fuchsu. ${ }^{37} \mathrm{~V}$ čas po vstopu Savina v slovensko glasbeno javnost pa je umestil le še tri nemške skladbe, od katerih je ena ostala nedokončana. Cvetkova pripoved, podprta tudi s skladateljevimi razmišljanji o prihodnji ustvarjalni usmeritvi v jugoslovansko smer, ${ }^{38}$ izraža sklepanje, da se je Savin v sredini devetdesetih let popolnoma predal slovenskemu nacionalnemu gibanju in služenju slovenski glasbeni kulturi.

Korigirana kronologija pa opozarja na možnost, da je Savin vse do začetka dvajsetih let kontinuirano ustvarjal nemške pesmi za glas in klavir v podobnem obsegu kot slovenske. Pobude za to so brez dvoma dajali družabni stiki, ki jih je navezal v tujejezičnem okolja, v katerem je dolga leta bival. Vanj se je lahko - tako duhovno kot jezikovno - vključil brez težav. Izhajal je iz spodnještajerskega malomestnega okolja, v katerem je bila brez občutnejših konfliktov vse do sredine 19. stoletja uveljavljena izrazita diglosija. Slovenščina je bila sicer sprejet in samoumeven jezik ruralnega okolja, a je bila funkcionalno omejena na vsakdanjo rabo. Vsa višja kultura je bila tesno povezana z uporabo nemškega jezika, ki je bil zato tudi pomemben označevalec družbenega položaja. Iz

37 Cvetko, Risto Savin ..., 23.

38 Cvetko, Risto Savin ..., 38-39. 
ohranjenega arhivskega gradiva lahko jasno razberemo, da se je Savin - ne glede na svojo morebitno zavestno nacionalno opredelitev - v izhodišču pogosteje in bolje izražal v nemščini, kot v slovenščini. S svojimi najožjimi sorodniki si je dopisoval v nemščini, za pisma v slovenščini pa je pogosto izdelal nemške koncepte ter jih je šele nato prevedel v slovenščino. Dominantno vlogo nemščine je še okrepilo dolgoletno bivanje v tujem, predvsem nemško govorečem okolju.

Njegovo izpopolnjevanje v uporabi knjižnega slovenskega jezika je bilo sorazmerno pozno in je bilo sámo dolgotrajen proces, ki se odraža tudi v njegovi ustvarjalnost za glas in klavir. Stik med melodijo in besedilom je v skladbah na nemška besedila veliko bolj naraven in doživet. Določene zadrege s prozodijo slovenskih besedil so opazne predvsem v zgodnjih slovenskih skladbah. Medtem ko se glasbena kritika Gojmir Krek in Anton Lajovic v ocenah Treh Aškerčevih balad za te spodrsljaje nista zmenila, je nanje opozoril prvenstveno literarni kritik Evgen Lampe ${ }^{39}$ (njegovo besedilo je Cvetko v monografiji popolnoma spregledal).

Predstava o Savinu kot prepričanem nacionalistu je zato brez dvoma zaznamovana s kasnejšim političnim in kulturnim razvojem in v svojem bistvu povsem ahistorična. Skladatelj je vse do popolnega preloma, ki ga je prinesel konec 1. svetovne vojne in razpad Avstro-Ogrske, poskušal premoščati naraščajoči prepad med kulturama. Vedno znova se je loteval nemških besedil, občasno si je prizadeval tudi za izvedbo svojih skladb v nemško govorečem delu Avstrije. ${ }^{40} \mathrm{~A}$ na svoji ustvarjalni poti je bil vedno močneje razpet med dva vsaksebi drveča svetova, dokler ga zgodovinske okoliščine niso privedle do tega, da je dokončno sprejel vlogo slovenskega skladatelja.

Od kod torej Savinova odločitev za uglasbitev dosežkov mladega slovenskega pesništva, ki so mu povzročali nemalo težav? Lahko ga razložimo predvsem z zavestno željo, da bi ohranil stik s svojo vedno bolj izključno slovensko domovino in vstopom $\mathrm{v}$ javnost nastajajoče nacionalne glasbene kulture. Ne smemo namreč pozabiti, da je Savin s svojimi stvaritvami stopal pred javnost, ki je v vedno manjši meri delila njegovo, $\mathrm{v}$ domačem okolju pridobljeno in med dolgotrajnim bivanjem v velemestih poglobljeno multikulturnost. Uporaba slovenskega jezika je bila pomembna - v slovenskih razmerah morda celo edina - izbira, ki je državljana Avstro-Ogrske opredelila kot Slovenca in ga ločila od pripadnikov drugih narodov. Zato je dejanje, ki bi bilo za skladatelja v drugačnih razmerah zgolj ena od ustvarjalnih odločitev, postalo ključno za ugoden odmev v njegov domači kulturni javnosti.

Druga ustvarjalna odločitev, ki jo je moral Savin sprejemati ob nastanku vsake od skladb, pa je zadevala njihovo glasbeno podobo. Cvetko je poskušal s svojo kronologijo poudariti stilni razvoj, ki naj bi se odvijal v skladateljevem ustvarjanju. Prve skladbe, zlasti tiste na nemška besedila, je zaradi ponekod jasne, zaokrožene oblikovanosti in nekoliko ožjega izbora harmonskih možnosti označil z zelo neposrečeno oznako »klasicistične». Na drugi strani pa opaža v skladbah na slovenska besedila pojav prvin, ki jih označuje kot »pozno romantične«, v slovenskem kontekstu celo »moderne ${ }^{41}$

\footnotetext{
39 Evgen Lampe, "Tri Aškerčeve balade«, Dom in svet 13, št. 3 (1900): 94-95.

40 Npr. dopisovanje s Sanneckom, ki je posredoval pri ponudbah za izvedbo opere Lepa Vida v Volksoper na Dunaju. Ograjenšek, Dopisovanje Rista Savina ..., 112.

41 Cvetko, Risto Savin ..., 35.
} 
Dopolnjen pregled pesmi in spremenjena kronologija tudi tu nekoliko spreminja našo sliko zgodovinskega dogajanja. Za številne »klasicistične« skladbe se izkaže, da so nastale hkrati z »modernističnimi«, včasih pa celo za njimi. Njihova drugačna podoba torej ne more biti posledica skladateljeve ustvarjalne nezrelosti ali nezmožnosti za uporabo širše palete skladateljskih rešitev. Podrobnejši pogled pokaže, da gre večinoma za bolj lirične skladbe, kjer je vsebina in struktura besedila ponujala manj možnosti za uporabo prekomponirane oblike ali zaostrenih harmonskih možnosti. Morda pa so njihovo podobo narekovale tudi povsem drugačne spodbude za njihov nastanek. Precejšen del tovrstnih skladb je očitno nastal za izvedbo v krogu Savinovih sorodnikov, prijateljev in znancev. Izvajalska zahtevnost skladbe je v mnogih prilagojena izvajalskim sposobnostim ljubiteljskih glasbenikov. Morda od tod tudi nekoliko skromnejše melodično oblikovanje, ki pred pevca ne postavljaja težjih nalog. Po pravilu pa je že v zgodnjih delih široko razvit klavirski part, ki ga je verjetno izvajal skladatelj sam in ga je zato lahko ustrojil po svojih, nikakor ne skromnih pianističnih sposobnostih.

Slovenski samospevi na drugi strani odražajo Savinovo željo, obogatiti slovenski repertoar za javno, koncertno izvedbo. Skladbe so zahtevnejše tako za izvajalce, kot za poslušalce in si jih težko predstavljamo izvedene v okvirih salonskega družabnega muziciranja. Za primer, kakšne so bile izvajalske zahteve v primerjavi s splošno ravnjo sposobnosti poklicnih glasbenikov, lahko navedemo dogajanje ob načrtovani izvedbi nekaj Savinovih samospevov na koncertih v začetku tridesetih let. Kot glavna ovira za uvrstitev skladbe na spored se je pokazala zahtevnost klavirskega parta samospeva $M a$ škarada, ki se ga pianist Anton Ravnik, sicer diplomant praške mojstrske šole in učitelj klavirja na Konservatoriju Glasbene matice, ni utegnil naučiti v dveh tednih, kolikor je ostalo do koncerta. ${ }^{42}$ Ustvarjalna brezkompromisnost in upoštevanje mednarodnih izvajalsko-tehničnih standardov, ki mu je prinesla navdušeno hvalo Gojmira Kreka in Antona Lajovica, je bila v skromno razvitem slovenskem kulturnem okolju morda najpomembnejša zavora pri širšem odmevu Savinovega ustvarjanja.

Dopolnjena kronologija Savinove ustvarjalnosti za glas in klavir tako narekuje opazovalcu drugačno pripoved, kot jo je opisal Dragotin Cvetko. Pokaže nam ustvarjalca, ki je bil razpet med dvema svetovoma, ki ju tako jedrnato podaja v času skladateljevega delovanja pogosto uporabljana sintagma »dom in svet«. Družinsko okolje, šolanje in vztrajno glasbeno izobraževanje v velikih središčih Avstro-Ogrske so ga pripravili na vstop v okolje nemško zaznamovane srednjeevropske kulture. S svojimi skladateljskimi sposobnostmi je v njem zasedel mesto osupljivo veščega diletanta, ki bi si lahko s kakšnim od boljših del morda celo utrl pot na koncertni ali operni oder. A nacionalno gibanje na slovenskem etničnem ozemlju, s katerim se je zaradi domačijske navezanosti čutil vedno bolj povezan, mu je odprlo novo pot. S svojim skladateljskim znanjem je v ustvarjalno revnem okolju nastajajoče slovenske nacionalne kulture postal eden od najpomembnejših ustvarjalcev svoje generacije.

42 Ograjenšek, Dopisovanje Rista Savina ..., 135-136. 


\section{SUMMARY}

Risto Savin wrote music for voice and piano from his study days in Vienna (ca. 1891) until the late 1920s when he wrote his last song, Maškarada ('Masquerade'). In this time span he planned, composed, or finished 41 pieces. He composed his songs on German (16) as well as Slovene (25) texts. The established chronology by Dragotin Cvetko artificially separates this creativity into two clearly divided periods: the German songs are supposed to fall mainly in the time when Savin studied with Robert Fuchs in Vienna; while after the mid-1990s when Savin actively joined the Slovene national movement, he was supposed to have reverted to composing primarily Slovene songs. Based on the surviving manuscript material, the author of the present paper offers a different chronology, which considerably alters our understanding of Savin's works for voice and piano. It is demonstrated that Savin sporadically continued to write German songs until the end of World War I and the collapse of the Austro-Hungarian empire. Both poles of Savin's creativity in the genre separate themselves into two different responses to his creative impulses: the German one as a means for establishing the technically-skilled amateur composer in the musically-apt social environment of the large centres of the monarchy in which Savin worked thoroughout his career; and the Slovene one as the key, developmental and ambitious contribution to the meagre but rising Slovene musical culture. 